\title{
Uzroci društveno-kulturnih različitosti između otočno-primorskog i zagoranskog dijela Dalmacije
}

Saša Mrduljaš*

Sasa.Mrduljas@pilar.hr
UDK: 930.85(497.5-3 Dalmacija) Pregledni članak / Review Primljeno: 26. listopada 2015. Prihvaćeno: 9. svibnja 2016.

Do završnice srednjeg vijeka hrvatski su prostori, sukladno različitosti političkih, zemljopisnih, inozemnih utjecaja, iskazivali izvjesne posebnosti i razvojne neujednačenosti. Unatoč tome bili su društveno-kulturno kompatibilna cjelina stabilno ukorijenjena $u$ vlastitoj civilizaciji te uglavnom uspijevala pratiti razvojne tokove unutar nje. Osmanskim osvajanjima, koja otpočinju polovicom 15. stoljeća, i po tom će se pitanju zbiti bitne promjene. Civilizacijski kontinuitet očuvat će se samo na obranjenim teritorijima, odnosno u sjeverozapadnoj $\mathrm{Hr}$ vatskoj, na otočno-primorskom pojasu pod mletačkom vlašću te u Dubrovačkoj Republici. Na osvojenom tlu Osmanlije su potpuno zbrisale dotadašnju, zapadnjačku društvenu strukturu. Hrvatima tih prostora jedina spona sa vlastitom civilizacijom ostala je Crkva i to svedena na franjevački red. U ovom radu analiziraju se promjene koje su u društveno-kulturnom kontekstu zbile unutar današnje Dalmacije tijekom osmanskog nadzora nad znatnim dijelom njena teritorija te razlozi zbog kojih su, nakon oslobođenja tih teritorija, za mletačke, francuske i austrijske vlasti, uspjele očuvati promjene koje su se zbile pod Osmanlijama.

Ključne riječi: Dalmacija, Hrvati, Mletačka Republika, Osmansko Carstvo, Austrija.

\footnotetext{
* Dr. sc. Saša Mrduljaš, viši znanstveni suradnik, Institut društvenih znanosti Ivo Pilar - Područni centar Split, Poljana kraljice Jelene 1/1, HR-21000 Split.
} 


\section{Uvod}

Prvi i najsnažniji doživljaj o dalmatinskim Hrvatima, kako u samoj Dalmaciji tako i u onim krajevima gdje ih se doživljava kao takve, jest da su osobita grupacija hrvatskoga naroda određena vlastitim izričajem mediteranskog identiteta. Njihove međusobne različitosti, koje proizlaze iz pripadnosti različitim sredinama unutar Dalmacije, također su prepoznatljive. S tim da ih se uglavnom percipira kao uobičajene razlike koje, baš kao i drugdje, proizlaze iz zemljopisnih zadanosti i posebnosti lokalnih sredina. Međutim, takva percepcija u kontekstu Dalmacije umanjuje sposobnost njenog shvaćanja te je tek uvjetno primjenjiva.

Najdalekosežnija društveno-kulturna distinkcija u Dalmaciji jest ona između otočno-primorskog i zagoranskog dijela. Pojednostavljeno, njeno bi se izvorište moglo dovoditi u svezu sa životom uz ili podalje od mora. Svakako da je i to utjecalo na pojavu nekih specifičnosti kod stanovništva otočno-primorske i zagoranske Dalmacije. No, one u ukupnosti razlika između tih dviju cjelina imaju perifernu ulogu. Iz jednostavnog razloga što je na njihovu pojavu geografski faktor, mada se uvelike poklapaju s njim, imao tek sekundarno značenje. U tom smislu minoran su utjecaj imale $\mathrm{i}$ »spontano « producirane lokalne posebnosti. One se trebaju uzeti u obzir, no prije svega kada se izdvojeno analizira otočno-primorski, odnosno zagoranski pojas.

Društveno-kulturna različitost »dviju« Dalmacija prvenstveno se oblikovala i održavala pod (in)direktnim utjecajem politike. Stoga je uvid u političku povijest Dalmacije početna točka od koje treba krenuti. U ovom radu upravo smo se bavili tim, »prvim poglavljem« tj. zbivanjima, događajima i pojavama koje objašnjavaju nastanak društveno-kulturnih razlika te njihovo koegzistiranje $u$ svojevrsnoj izvornoj formi tj. za vladanja, uvjetno rečeno, katoličkih država nad Dalmacijom (Mletačka Republika, Francuska, Austrija). Formiranjem Kraljevine Srba, Hrvata i Slovenaca 1918. te akceleracijom modernizacijskih procesa hrvatsko društvo sa svojim dalmatinskim segmentom ulazi u razdoblje koje čini zasebnu povijesnu dionicu.

O Dalmaciji, njenom razvoju i identitetima, pisalo se relativno mnogo. Međutim, moglo bi se reći da nedostaje izravnih i koliko-toliko zaokruženih odgovora na pitanja koja se odnose na problematiku njene društveno-kulturne podvojenosti te utjecaja koje je ona imala ili, prilagodbom suvremenim tijekovima, i nadalje ima na zbilju Dalmacije i ukupnog hrvatskog društva. Cilj je ovoga rada da se na temelju odgovarajućih, postojećih saznanja, njihove primjerene sinteze te spoznaja koje iz takve sinteze mogu proizići pruži što obuhvatniji uvid u predmet razmatranja. Takvi, »sveobuhvatni« odgovori, naročito ukoliko su pruženi u kondenziranoj formi, podložniji su kritici i korekcijama te time donekle nezahvalni. No, bilo kako bilo »ploviti se mora«. 


\section{Temeljni kulturni identitet Dalmacije}

Pojava civiliziranog društva na tlu današnje Dalmacije, takvog koje uključuje grad, koje se koristi pismom, koje je prožeto složenijim oblicima socijalne organizacije, zbila se prije gotovo dvije i pol tisuće godina. Uzme li se u obzir istovrsne tijekove na općoj pa i europskoj razini, to se dogodilo relativno rano. No civilizacija unutar Dalmacije nije bila samonikla niti se razvila pod utjecajima naprednijih središta. Bila je importirana doseobom Grka te formiranjem njihovih kolonija. One su obuhvatile manje dijelove dalmatinske obale i za svog višestoljetnog trajanja nisu uspjele potaći civilizacijsko oblikovanje ilirskih zajednica u svom okruženju. Bitne promjene nastupaju početkom nove ere, kada Rimskom Carstvu uspijeva čvrsto podvlastiti ovdašnje krajeve, a time i dovršiti uklapanje jugoistočne Europe u vlastiti okvir. ${ }^{1}$ Premda je primarno bila riječ o političkom činu, on je imao i dalekosežne kulturne posljedice. Ne samo da su granice civilizacije, promatrano u europskom kontekstu dislocirane do sjevernih granica rimske države, već su zatečena rodovsko-plemenska društva izložena romanizaciji. Tako su vremenom i ilirski krajevi uvelike integrirani u rimsko-latinski krug. To se možda najbolje očitovalo u činjenici ilirskog podrijetla više rimskih careva. ${ }^{2}$

Urušavanjem Rimskog Carstva te svođenjem njegovih bizantskih ostataka na Malu Aziju, došlo je i do svojevrsnog raspadanja civilizacije na europskom kontinentu. Ono je bilo djelomično na prostorima gdje se održao romanski živalj pod vlašću germanskih, nekoć u službi Carstva angažiranih rodovskovojnih skupina. ${ }^{3} \mathrm{Na}$ pojedinim pak točkama došlo je do potpunog raskida s dotadašnjim tijekovima. Primjerice na nekadašnjem rimskom dijelu Britanije te poslije na Balkanu kojeg su do Peloponeza naselile slavenske grupacije. ${ }^{4}$ Kontinuitet antičke civilizacije na tlu Europe očuvao se tek unutar rijetkih enklava koje su ostale pod bizantskom vlašću i koje su naknadno uspjele steći samostalnost ili značajan oblik autonomije unutar u međuvremenu nastalih država. Tih enklava, konkretno unutar romansko-jezične sfere bilo je samo na tlu Italije te na istočnojadranskoj obali. U prvom slučaju riječ je o Rimu, Veneciji i pojedinim južno-talijanskim središtima, a u drugom o nizu otoka i gradskih naselja koji su se glavninom nalazili u sklopu upravne jedinice koja je nastavljala nositi ime Dalmacije. Među te istočnojadranske otoke i gradove pripadali su Krk, Cres-Lošinj, Rab, Zadar sa susjednim otocima, Trogir, Split, Dubrovnik, Kotor, Budva i Bar. Riječ je bila o stvarnim ostacima Rimskog Carstva koji su

\footnotetext{
${ }^{1}$ Usp. Petar LISIČAR, Grci i Rimljani, Zagreb, Školska knjiga, 1971.

2 Usp. Aleksandar STIPČEVIĆ, Iliri, Zagreb, Školska knjiga, 1989, 55-57.

${ }^{3}$ Usp. Miroslav BRANDT, Srednjovjekovno doba povijesnog razvitka, Zagreb, Školska knjiga, 1995.

${ }^{4}$ Usp. Fransis KONT, Sloveni (I), Beograd, Retrospektive, 1989, 46.
} 
i nakon jezične slavenizacije nastavljali čuvati te vremenu prilagođavati svoj drevni identitet.

Rimsko-bizantska dalmatinska središta sama po sebi nisu mogla izvršiti nekakav radikalan utjecaj na društvenu strukturu njima susjednih, početkom 7 . stoljeća doseljenih slavenskih, odnosno hrvatskih skupina. Kao i u prethodnom grčko-ilirskom slučaju trebao je postojati faktor sile koji bi potakao uključivanje rodovsko-plemenskih zajednica u postojeće civilizacijske okvire. Kod Ilira je tu ulogu odigralo Rimsko, a u Hrvata, kao i u dijela drugih europskih naroda, Franačko Carstvo. Unatoč tomu što je u svojem inicijalnom obliku to carstvo kratko trajalo, imalo je izrazit utjecaj na daljnji razvitak Europe. Prvenstveno po tome što je dotadašnjim razvojnim tijekovima uspjelo dati stabilnu formu te omogućiti njihov utjecaj na znatan dio europskoga kontinenta. Posebnu važnost imali su franački poticaji političkoj subjektivizaciji papinstva, a time i Crkve kojom je papa upravljao. Na taj je način omogućeno da unutar zapadne Europe Rim iznova postane najsnažnijim regeneratorom i promotorom civilizacijskih vrijednosti. ${ }^{5} \mathrm{Na}$ istoku europskoga kontinenta, no nešto poslije i u vlastitoj medijatorskoj formi, tu će ulogu preuzeti Bizant.

Franačka je početkom 9. stoljeća zauzela znatan dio hrvatskih prostora te potakla kristijanizaciju ovdašnjeg življa što je ujedno bila inicijacija u zapadni krug. Unutar njega su postojala ili nastajala središta koja će biti presudna u daljnjem oblikovanju identiteta i razvoja Zapada. No kojom će se brzinom i koliko njihovi utjecaji širiti i ukorjenjivati u pojedinim segmentima tog kruga ovisilo je i o njihovim predispozicijama. U tom smislu Hrvatskoj je pogodovalo što se nalazila uz istočnojadranske preostatke rimskog svijeta. Oni su itekako mogli doprinijeti njenom svestranom povezivanju s civilizacijom kojoj su kontinuirano pripadali i s čijim su središtima bili u živoj vezi. Kristijanizacijom Hrvata, pa i time što i kod njih latinski preuzima ulogu službenog jezika, stvoren je osnovni preduvjet kompatibilnosti romansko-dalmatskog i hrvatskog društva. Ubrzo su uslijedili interakcijski, a zatim i integracijski procesi. U blizini romanskih gradova nalazila su se ranosrednjovjekovna središta hrvatska države, kao i najznačajniji oblici hrvatske materijalne kulture. Nakon organizacijskog "stapanja« dalmatinske i hrvatske crkve početkom 10. stoljeća, Split postaje sjedištem hrvatskog katolicizma. Tijekom 11. stoljeća okončano je i političko uvezivanje te od tada hrvatski vladari vladaju Kraljevstvom Hrvatske i Dalmacije. ${ }^{6}$ Početkom 12. stoljeća, prelaskom državnog sjedišta u Ugarsku, a time i slabljenja hrvatskog državnog položaja, splitski nadbiskup, kao »primas Dalmatiae atque totius Croatiae« ostaje jednim od najstabilnijih čimbenika u očuvanju hrvatske etno-teritorijalnosti. ${ }^{7}$ Napokon, dalmatinske sredine, koje s

\footnotetext{
${ }^{5}$ Usp. August FRANZEN, Pregled povijesti Crkve, Zagreb, Kršćanska sadašnjost, 1993.

${ }^{6}$ Usp. Ferdo ŠIŠIĆ, Povijest Hrvata u doba narodnih vladara, Zagreb, Matica hrvatska, 1990, $469,523,652$.

7 Usp. Josip TURČINOVIĆ, Katolička crkva u južnoslavenskim zemljama, Zagreb, Kršćanska sadašnjost, 1973, 16.
} 
vremenom stječu specifičan tj. komunalni organizacijsko-pravni status, koji je u slučaju Dubrovnika bio podlogom oblikovanja državnosti, uglavnom će do 14. stoljeća biti i jezično kroatizirane te postaju sastavnim dijelom hrvatskog etničkog korpusa i identiteta. ${ }^{8}$

Do završetka srednjeg vijeka postojale su neke, pa i uočljivije razvojne razlike između jadranskih, krško-planinskih te panonskih dijelova hrvatske etničke zajednice. One su bile uvjetovane različitošću povijesnog nasljeđa, zemljopisnog smještaja, državno-pravnog položaja te porijekla inozemnih utjecaja. Tako su na tlu današnje Dalmacije društvenu razinu nekoć romanskih sredina uvelike dosegli pojedini primorski krajevi i otoci. Posebice oni koji su uspjeli oblikovati komunalni ustroj te na koje se također protegnulo dalmatinsko ime. ${ }^{9} \mathrm{U}$ zaleđu je nedostajalo izražajnijeg urbanizma, jednog od važnijih obilježja uznapredovanih društava. ${ }^{10}$ No bile su stvorene materijalne i socijalne pretpostavke za njegov daljnji razvoj. Postojale su utvrde pod kojima su se postupno oblikovala pripadajuća im naselja. Tu je bila i složena društveno-statusna diferencijacija koja je, kako je pokazao daljnji razvoj Zapada, bila nužan temelj svakog napretka. Presudno obilježje hrvatskih prostora, pa i onih koje zauzima današnja Dalmacija, bilo je u istovrsnosti njihove etno-konstituirajuće osnovice, odnosno $u$ istojezičnosti ovdašnje populacije te u njenoj pripadnosti katoličkoj vjeri. No pored toga, njihova bitna karakteristika, unatoč svim raznolikostima, bila je i u tome što su bili društveno kompatibilni, međusobno povezani te što su, općenito gledano, uspijevali pratiti razvojni ritam vlastitih civilizacijskih središta.

\section{Mletačka i osmanska Dalmacija}

Važan utjecaj na sveukupnu stvarnost hrvatskih zemalja, takav koji će svoje značenje umnogome zadržati do danas, proizašao je za osmanskih osvajanja i njihove dominacije nad glavninom ovdašnjih teritorija. Najdalekosežniji je bio utjecaj etničkih promjena. Naime, nakon osmanskog zauzimanja Bosne 1463. oblikuje se relativno stabilan hrvatsko-ugarski obrambeni sustav. Osmanlije ga postupno urušavaju tako što pustoše zemlje koje su bile njegovom logističkom osnovom. Time je hrvatski živalj osvajanih zemalja bio izložen, osim pogibijama u čestim sukobima, masovnim porobljavanjima i deportacijama u udaljene dijelove Osmanskoga Carstva. Da bi izbjegao tu sudbinu taj se narod znatnim dijelom i iseljavao u sigurnije, pretežito inozemne krajeve. Na koncu, Osmanlije tijekom 16. stoljeća urušavaju prvotne obrambene linije, te se one na hrvatskim

\footnotetext{
${ }^{8}$ Usp. Radoslav KATIČIĆ, Litterarum studia, Zagreb, Matica hrvatska, 1998, 583-592; Grga NOVAK, Prošlost Dalmacije (I). Split, Marjan tisak, 2004, 152-155.

${ }^{9}$ Usp. Novak, Prošlost Dalmacije (I)..., 117-118.

${ }^{10}$ Usp. Tomislav RAUKAR, Hrvatsko srednjovjekovlje. Prostor, ljudi, ideje, Zagreb, Školska knjiga - Zavod za hrvatsku povijest Filozofskog fakulteta u Zagrebu, 1997, 143-150.
} 
teritorijima konsolidiraju nekih stotinu i pedeset kilometara zapadnije, čime Osmanlije zauzimaju najveći dio hrvatskih zemalja. No te su zemlje bile puste. Znatniji izuzetak je bila današnja Slavonija koja je zbog relativno brzog pada uspjela zadržati dio svog domicilnog stanovništva. ${ }^{11} \mathrm{Na}$ opustošene prostore osmanska vlast pretežito kolonizira srpsko-pravoslavni živalj te nekad središnji hrvatski krajevi postaju pretežito nastanjeni Srbima. ${ }^{12}$ Pored toga, pod osmanskom je vlašću, tijekom prve polovice 16. stoljeća pokrenut proces masovne islamizacije uglavnom bosanskog katoličkog življa. Time je stvorena osnova za formiranje nove, bosansko-islamske etničke zajednice čijim će dijelom postati i ovdašnje, manje islamizirane grupacije koje nisu bile bosanskog teritorijalnog porijekla. ${ }^{13}$

Znatne promjene su se zbile i na socijalnoj razini kod onog dijela hrvatske populacije koja je dospjela pod osmansku vlast. Dotadašnji društveni red bio je posve urušen. Osmanlije su zbrisale gornji sloj hrvatskoga katoličkog društva, a koji je bio presudan za njegovu povezanost s tokovima vlastitih civilizacijskih središta. Od nekadašnjih društvenih institucija očuvala se jedino Crkva uglavnom svedena na franjevački red. ${ }^{14} \mathrm{U}$ materijalnom smislu i njena je nazočnost bila neuočljiva. Crkvene zgrade i samostani su paljeni i rušeni te u pravilu nisu obnavljani, a novi se nisu smjeli graditi. Stoga su se čak i vjerski obredi najčešće održavali u improviziranom uvjetima. Doduše, pod osmanskom vlašću oblikuju se nove lokalno-vladalačke strukture koje konzumiraju i produciraju vrijedne kulturne tekovine. Ali riječ je bila o muslimanima koji u tom smislu doprinosili muslimanskoj-bosanskoj zajednici. Pod osmanskom vlašću je i urbanizam doživio neku vrstu poleta. ${ }^{15}$ No riječ je o bila muslimanskom gradu od kojeg je kršćansko, seljačko stanovništvo bilo oštro odijeljeno. Ono je, onoliko koliko nije izvrgnuto islamizaciji, bilo tolerirano, ali segregirano od islamskoga, vladajućeg društva.

Nakon osmanskih osvajanja s kraja 15. i početka 16. stoljeća prostor je današnje Dalmacije podijeljen između dvije civilizacijske sfere. Na uskoj priobalnoj liniji približno između Novigrada i Splita te na otocima održala se kršćanska, konkretno mletačka vlast. Pored toga na jugu je opstala i Dubrovačka Republika koja je uspijevala osigurati mirnu koegzistenciju sa susjednim Osmanlijama. Tako se na tim dijelovima Dalmacije, nastanjenom čakavskim ili novoštokavsko-ijekavskim življem, uspijevalo očuvati kontinuitet društvenih institucija i

\footnotetext{
${ }^{11}$ Usp. Ive MAŽURAN, Hrvati i Osmansko Carstvo, Zagreb, Golden marketing, 2004.

${ }^{12}$ Usp. Vasa ČUBRILOVIĆ, Seobe i etničke promjene u jugoslavenskim pokrajinama od V. do početka XIX. stoljeća, u: Branislav ĐURĐEV i dr. (ur.), Historija naroda Jugoslavije (II), Zagreb, Śkolska knjiga, 1959, 840-853.

${ }^{13}$ Usp. Srećko M. DŽAJA, Konfesionalnost i nacionalnost BiH, Sarajevo, Svjetlost, 1992.

${ }^{14}$ Usp. Franjo ŠANJEK, Kršćanstvo na hrvatskom prostoru, Zagreb, Kršćanska sadašnjost, 1991, 278-284.

${ }^{15}$ Usp. Mustafa IMAMOVIĆ, Historija Bošnjaka, Sarajevo, Bošnjačka zajednica kulture Preporod, 1998, 181-225.
} 
odnosa. S tim da su između mletačke Dalmacije i Dubrovnika postojale izvjesne razlike u mogućnostima primjene razvojnih dostignuća civilizacije u kojoj su bili ukorijenjeni.

Naime, mletačko zauzimanje najvećeg dijela istočnojadranske obale, provedeno do polovice 15. stoljeća, bilo je motivirano željom za osiguranjem vlastitih plovidbenih putova te radi dokidanja, u odnosu na Veneciju, konkurentske sposobnosti ovdašnjih središta. U jezgri mletačke politike bilo je urušavanje razvojnog potencijala ovdašnjih sredina i njihovo svođenje na razinu "perifernih postaja mletačkih prekomorskih posjeda «. ${ }^{16}$ Sukladno tome, dalmatinske su komune, od kojih je većina imala istu rimsko-bizantsku ishodišnu točku kao i Venecija, zadugo odbijale mletačku vlast i svoju zaštitu tražile pod okriljem udaljenih, za njihovu autonomiju afirmativnih hrvatsko-ugarskih kraljeva. Prodorom Osmanlija i brisanjem hrvatsko-ugarske vlasti iz zaleđa dalmatinskih sredina, potpuno se mijenja značenje Mletačke Republike. S obzirom na to da je jedino ta država mogla garantirati opstojnost dalmatinskih komuna, one su u promijenjenim uvjetima čvrsto stajale uz nju. I uistinu, u tom je smislu uloga Venecije bila nemjerljiva. Braneći svoje pozicije branila je i obranila civilizacijski kontinuitet dalmatinskog priobalja i otoka. Međutim u »prirodi« same Republike bilo je da ne ide puno dalje od toga. Tako je mletačka Dalmacija u ekonomsko-razvojnom smislu ostajala u vrlo skučenom okviru.

Dodatnom zaostajanju mletačke Dalmacije, prvenstveno priobalnih komuna, doprinosilo je i to što im je osmanskim osvajanjima znatno sužen nekadašnji zemljišni posjed, a time i ekonomska osnovica. U promijenjenim prilikama one su bile svedene na prostorno skučen utvrđeni pojas krških, uvelike pasivnih krajeva. S tim da se niti taj skroman posjed nije moglo valjano iskoristiti. Ne samo da se živjelo pod stalnom egzistencijalnom prijetnjom ili u ratnim uvjetima, već su ti isti posjedi za čestih sukoba s Osmanlijama pustošeni. Time je dodatno urušavan razvojni potencijal nekada naprednih dalmatinskih komuna. One su bile u prilici, baš kao i Dubrovnik, zadržati svoju aristokraciju, građanstvo, složenu društvenu strukturu, zakone, red te pratiti razvojne tokove. No, s obzirom na ekonomsku slabost, sve im je teže bilo prilagođavati se tim tokovima, a posebice kreativno sudjelovati u njima. Štetnost takvog razvoja primarno se osjećala u sredinama o kojima je bila riječ. No uzme li se u obzir da su na hrvatskom jugu upravo te sredine, uz geografski periferno smješteni Dubrovnik, jedine očuvale autentičnu društvenu formu, tad je razumljivo da je njihovim slabljenjem slabila i cjelina južnohrvatske etničke formacije.

Na prostoru današnje Dalmacije, zaleđe je priobalnih mletačkih posjeda te primorje između Splita i zapadnih granica Dubrovačke Republike, izuzimajući mletački Omiš, pod osmansku vlast dolazilo postupno. Približno gledano, krajevi istočno od Cetine uglavnom su brzo osvojeni i to nakon osmanskog

${ }^{16}$ Usp. Tomislav RAUKAR, Studije o Dalmaciji u srednjem vijeku, Split, Književni krug, 2007, 154. 
zauzeća Hercegovine 1471. Stoga se na njima očuvala glavnina starosjedilačkog hrvatskog življa štokavsko-ikavskog govora. Krajevi zapadno od Cetine osvajani su sve do 1537. godine kada pada zadnja, kliška utvrda. Nakon toga praktički je potpuno zbrisano njihovo domicilno, nekoć čakavsko stanovništvo. ${ }^{17}$ Izuzetak su bila Poljica koja su, zahvaljujući diplomatskom segmentu svoje politike, barem tijekom zauzeća, uspjela očuvati veći dio svoga življa. ${ }^{18}$

Pod osmanskom vlašću položaj je hrvatskih grupacija nastanjenih u krškim krajevima današnje Dalmacije i Hercegovine bio donekle drukčiji od položaja kojeg su imali Hrvati npr. u Bosni ili Slavoniji. Kao prvo, u krškim su krajevima Osmanlije znatnije uključile preostale hrvatske skupine u kolonizaciju sredina koje su prethodno opustošile. Premda je sjever današnje Dalmacije znatno naseljen Srbima, ipak je glavnina teritorija zapadno od Cetine kolonizirana hrvatskim štokavsko-ikavskim življem. Kao drugo, kršćanski, kako pravoslavni tako i katolički živalj nastanjen u krškim, pretežito za stočarstvo pogodnim područjima, Osmanlije su svele na tzv. vlaški status. Njegovi pripadnici, s ekonomskom osnovicom u stočarstvu, imali su manja porezna davanja, izvjesnu samoupravu pod svojim glavarima, ali i dužnost služenja u osmanskim vojnim formacijama. ${ }^{19}$ Ujedno, oni su znatno manje islamizirani te je u osmanskoj Dalmaciji bilo relativno malo muslimanskog, gotovo odreda štokavsko-ikavskog življa, pretežito nastanjenog u upravnim središtima i plodnijim zonama. ${ }^{20}$ Nadalje, Hrvati krških područja našli su se pod osmanskom vlašću u svojevrsnoj dvostrukoj izoliranosti. I oni su, poput ostatka svojih sunarodnjaka pod Osmanlijama, bili radikalno odvojeni od vlastitih civilizacijskih središta i tokova te im je franjevački red ostao jedinom institucionalnom poveznicom sa Zapadom. No, živeći u pasivnim, slabo islamiziranim predjelima te u okvirima svojih samouprava, bili su uvelike izolirani i od utjecaja osmansko-islamske kulture. Jedan od rezultata te izolacije bila je gotovo ista razina narodne kulture za trajanja dvjestogodišnje osmanske vlasti. Nju su Osmanlije »oslobodile« utjecaja katoličkoga feudalnog sloja, s kojom se »ušlo« u okvire islamskog sultanata i u osnovi ostajala istom. $\mathrm{S}$ tim da je prilagođavana ponajprije političkim uvjetima pod kojima se živjelo. Oni su pak u tom graničnom, perifernom pojasu u bitnome bili obilježeni nasiljem, bezakonjem i samovoljom lokalnih osmanskih vlastodržaca.

\footnotetext{
${ }^{17}$ Usp. Josip LISAC, Hrvatski dijalekti i jezična povijest, Zagreb, Matica hrvatska, 1996, 15.

${ }^{18}$ Usp. Vjeko OMAŠIĆ (ur.), Iz prošlosti Podstrane, Podstrana, Općina Podstrana, 1991, 110.

${ }^{19}$ Usp. Krešimir KUŽIĆ, Povijest Dalmatinske zagore, Split, Književni krug, 1997, 113-115; Milan VASIĆ, Martolosi u jugoslovenskim zemljama pod turskom vlašću, Sarajevo, ANUBiH, 1967.

${ }^{20}$ Usp. Pavo ŽIVKOVIĆ, Povijest BiH do konca 18. stoljeća i povijest Hrvata Bosanske posavine do početka 20. stoljeća, Mostar, HKD Napredak, 1994, 132.
} 


\section{Mletačke stare i nove stečevine}

Tijekom Kandijskog (1645-1669), Morejskog (1684-1699) i Malog rata (17141718) oslobođeni su oni dijelovi današnje Dalmacije koji su bili pod Osmanlijama. Time je postojeći mletački posjed uvećan tijkom zadnja dva rata s nekih $2.600 \mathrm{~km}^{2}$ za dodatnih gotovo $8.000 \mathrm{~km}^{2}$ (v. zemljovid br. 1). Još za vrijeme sukoba na oslobađanim je prostorima dolazilo do znatnih etno-demografskih promjena. Dok se muslimanko stanovništvo iseljavalo u susjedne dijelove $\mathrm{BiH}$, katolički i pravoslavni živalj je ostajao na svojim ognjištima. Pored toga dolazilo je, ovaj put pod mletačkim nadzorom, do novih masovnih useljavanja. Tako su u sjevernu Dalmaciju pristizale katoličke i pravoslavne grupacije iz Like i Bosanske krajine dok su u srednju Dalmaciju dolazili katolički doseljenici iz livanjskog, duvanjskog, ramskog kraja te iz Hercegovine. Poput znatnog dijela zatečene populacije i velik dio doseljenika bio je uključen u protuosmanske napore. ${ }^{21}$

U (geo)političkom smislu promjene nakon Morejskog i Malog rata bile su znatne. Do tada su Mlečani u priobalju pod svojom vlašću imali tek uzak utvrđeni pojas, kako je rečeno, između Novigrada i Splita. Okončanjem tih ratova ne samo da je oslobođen ostatak primorja, već su Osmanlije udaljene od obalne linije, ovisno o točki gledanja, od 10 do 80 kilometara. Što je posebice važno, više nisu bili prijetnja mletačkoj Dalmaciji. Napokon su bili stvoreni uvjeti za relativno mirnu egzistenciju. No da bi iz nje proizišao opći boljitak životnih prilika, a u konačnici i napredak, valjalo je ukloniti štetu koja je nastala iz stoljetnog osmanskog utjecaja. Naime, stari mletački posjedi mogli su imati značajnu ulogu i u revitalizaciji oslobođenih krajeva i biti predvodnikom ukupnog razvoja. $\mathrm{S}$ tim da im je trebalo omogućiti prevladavanja skučene i razvojno nepovoljne ekonomske osnovice na koju su ih svela osmanska osvajanja. S druge strane, na oslobođenim prostorima pitanje nadilaženja teških i nesređenih ekonomskih prilika bilo je dijelom šire problematike. Na njima je nakon dokidanja osmansko-islamske vlasti bilo nužno obnoviti gotovo kompletnu društvenu strukturu sukladnu zapadnim vrijednostima i zakonitostima. Dakle, istodobno je trebalo inicirati odgovarajuće promjene i na starim i na novim mletačkim posjedima. Tako da u konačnici ti posjedi, uz geografsku kompatibilnost i međuovisnost, steknu ujednačenost i na društveno-kulturnoj razini. Da budu čvrsto povezani s vlastitim civilizacijskim središtima te osposobljeni za praćenje i sudjelovanje u aktualnim razvojnim tokovima.

S obzirom da je još uvijek bila riječ o vremenu u kojem feudalizam, premda u zalaznoj fazi, čini okvir strukturiranja društveno-ekonomskih odnosa, promjene se moglo provesti samo unutar prikladne feudalne forme. Pri tome je bilo posebno važno da se na teritoriju kojeg je obuhvaćala tadašnja Dalmacija

\footnotetext{
${ }^{21}$ Usp. Mile BOGOVIĆ, Katolička crkva i pravoslavlje u Dalmaciji za mletačke vladavine, Zagreb, Kršćanska sadašnjost, 1982, 6-21.
} 
iznova regenerira snažna veleposjednička aristokracija. Na starim je posjedima bilo aristokracije, no raspolagala je skromnim zemljišnim fondom kojeg se uspjelo očuvati za stoljetnih ratovanja. ${ }^{22} \mathrm{Na}$ novostečenim su prostorima vladale drugačije prilike. Kao što su nekoć hrvatski veleposjednici bili zbrisani od strane Osmanlija, sada su, u sklopu kršćanske rekonkviste, bili uklonjeni osmanski. Sveukupno, spomenutih gotovo $8.000 \mathrm{~km}^{2}$ valjalo je iznova prožeti veleposjedima. S tim da se u interesu razvitka Dalmacije moralo voditi brigu i o tome kome omogućiti vlasništvo nad njima. U prvom redu valjalo je posjednicima u primorskim i otočnim komunama omogućiti da obnove svoje vlasništvo nad zemljištem koje su izgubili tijekom osmanskih osvajanja, odnosno da ga na temelju zasluga u oslobađanju olakšano stječu. Time bi se primorsko-otočne sredine, osim prema moru, usmjerilo i k prirodnom zaleđu i to na obostranu korist. Nadalje, valjalo je istaknute pojedince s oslobođenih krajeva nagraditi znatnim posjedima te im omogućiti da ih olakšano uvećavaju. Na ovaj bi način bio stvoren posebno značajan veleposjednički sloj koji bi u pravilu obitavao tamo gdje ima posjede. Napokon, sukladno tadašnjem vremenu i političkim odnosima, razumljivo da bi velik dio zemljišta pripao i strancima. Takvima koji su stekli zasluge u oslobađanju te onima koji bi imali sredstava da od države kupe posjede. Strano porijeklo ne bi umanjivalo njihov doprinos ekonomskom i društvenom razvitku krajeva u kojima bi imali posjede. Ako bi s vremenom to postalo razlogom pokušaja blokade npr. političkih zahtjeva naroda, tad bi dosegnuti razvitak tom istom narodu olakšao neutralizaciju tih pokušaja.

U epohi oštre staleške podvojenosti, u kojoj su veliku većinu činili niži slojevi, razumljivo da je malobrojna aristokracija najčešće doživljavana negativno. Takvo raspoloženje poticano je nizom razloga, u rasponu od bahatosti gospodujućih pa do zavisti niže rangiranih. No u vremenu u kojem je zemlja bila temeljnim izvorom prihoda, bilo je potrebno iskoristiti je na najbolji način, odnosno u što većoj mjeri privesti je proizvodnji, proizvesti što više, kvalitetom proizvoda nadjačati konkurenciju, plasirati proizvode na tržište, prodati ih te steći bogatstvo. Da bi se sve to uspjelo jednostavno je trebao postojati veleposjednički sloj. Takav da je zbog veličine svojih posjeda ne samo zainteresiran za inovacije i unaprjeđenje proizvodnje već da to može i osigurati. Sloj koji utječe i na razvoj trgovine, obrazovanja, kulture, umjetnosti te time, mada vođen vlastitim interesima, osigurava i snagu šireg društvenog kruga. Koliko god Dalmacija bila krševitom zemljom, pružala je uvjete za razvitak veleposjedništva. Napokon, unutar postora kojeg je zauzimala početkom 18 . stoljeća, nekad je bilo središte hrvatske države pod dinastijom Trpimirovića, a naknadno i ekspanzivnih knezova bribirskih iz roda Šubića. Knezova od kojih je potekla najznačajnija hrvatska feudalna dinastija Šubića-Zrinskih. I u slučaju Trpimirovića i u slučaju Bribirskih, raspolaganje znatnim zemljišnim posjedom

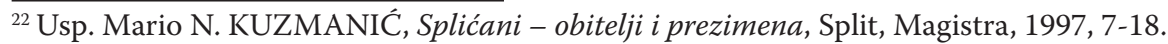


(i) unutar današnje Dalmacije bilo je presudno u afirmaciji i tih obitelji i sredine u kojoj su bili ukorijenjeni. Jasno, u drugačijem povijesnom kontekstu.

Dok je na starim posjedima snažan veleposjednički sloj bio potreban radi aktiviranja postojećih potencijala, na oslobođenim je teritorijima njegova uloga trebala biti dalekosežnija. Naime, onaj tko raspolaže bogatstvom nužno je zainteresiran za red i sigurnost te bi se potrudio da se u takvom ozračju živi i djeluje. Ubrzao bi urbanizaciju postojećih vojno-upravnih centara, a vjerojatno utjecao i na umnožavanje gradskih sredina. Na koncu, bio bi jezgrom društvene elite koja bi bila svojevrsnim uzorom okolnom stanovništvu. Ono bi se stoga, onoliko koliko je moguće prilagođavalo »trendovima « vlastitog civilizacijskog kruga. Pored toga, feudalizacijom stvorena društvena diferencijacija vodila bi diferencijaciji interesa. Iz nje bi proizlazila društvena dinamika koja uključuje i dinamiku na polju ideja. I sve to skupa oslobođenim bi prostorima omogućilo da tijekom vremena »uhvate korak« sa zapadnim, mediteranskim sredinama kojima je povijesni razvoj bio naklonjeniji. U svakom slučaju, u Dalmaciji je nakon Morejskog i Malog rata valjalo provesti opsežne promjene da bi ta zemlja adekvatno funkcionirala. Do njih nije moglo doći zalaganjem društvenih struktura unutar same Dalmacije. Stoga je primarno bilo na državnim vlastima da osmisle karakter i način provedbe promjena te da ulože napor u njihovo provođenje. Nažalost, unatoč tome što su rečenim ratovima stvorene pretpostavke koje su mogle osigurati povoljnije prilike u Dalmaciji, one gotovo da i nisu iskorištene.

Mletačka je Republika na oslobođenim prostorima uvelike zadržala postojeće društveno stanje prilagodivši ga vlastitim prilikama. Za razliku od nekad proširenog vlaškog, sada se stanovništvo tih krajeva, premda nakon 1718. nije bilo sukoba s Osmanlijama, našlo u približno sličnom mletačko-krajiškom statusu. Zatečenom i doseljenom življu zemlja je prepuštana na korištenje onoliko koliko se smatralo potrebnim da zadovoljava vlastite egzistencijalne potrebe. S tim da su prepuštana imanja ostajala u državnom vlasništvu. Politički ili vojno zaslužnim pojedincima na upotrebu su davani veći posjedi. Time je doduše iz ukupne populacije formiran viši sloj, no bez potencijala za znatniju preobrazbu sredina kojima je pripadao.

Na oslobođenim prostorima zapravo je podržan sustav kojeg je i sam narod priželjkivao. On je naizgled i bio bolji jer je svakome davao ponešto i oslobađao pritiska veleposjednika. Druga je stvar što je on dugoročno imao štetne ekonomske i društvene posljedice za krajeve gdje je postojao. Njegova je primjena imala smisla i u kontekstu zaštite mletačkih pozicija u stečenim krajevima. Jer nekim se mjerama trebalo zadržati živalj na njima. U suprotnom je postojala mogućnost da nekadašnji osmanski podanici, koliko god bili vjernim kršćanima, isele pod osmansku vlast ako ona pruža bolje egzistencijalne uvjete. Opet, 
Mlečani nisu imali pretjeranog povjerenja u lojalnost dalmatinske elite te je nisu htjeli jačati na starim niti stvarati na novim teritorijima. ${ }^{23}$

Sve u svemu, unatoč tome što se Dalmacija početkom 18. stoljeća riješila osmanskog pritiska, stekla povoljniji geopolitički položaj te ekonomsku osnovu pogodnu za daljnji razvitak, državnom je politikom onemogućeno da znatnije iskoristi te pogodnosti. Pri tome je od manjeg značenja bila već ustaljena, sputavajuća mletačka politika prema Dalmaciji. Na toj se razini moglo praktički jednom političkom odlukom promijeniti stanje stvari. No time što se dopustilo da ova stoljetnim sukobima iscrpljena zemlja ostane trajno podijeljena na dvije društveno, ekonomski, pravno neuvezane pa i nekompatibilne zone, koje su u stvarnosti međuovisne, stvoren je trajan problem $\mathrm{s}$ teško nadvladivim posljedicama. Tako je u promijenjenim okolnostima nekadašnja mletačko-osmanska crta razdvajanja postala crtom koja unutar istog političko-državnog okvira odvaja dva društva. ${ }^{24}$ Pri tome je svako od njih nastavljalo egzistirati sukladno vlastitim specifičnostima i teškoćama.

Stare, društveno-imovinski izdiferencirane komunalne sredine, nastavile su funkcionirati po zapadnom vrijednosnom sustavu i razvojnom ritmu. No, budući da im nije dopušteno da se gospodarski obnove te dodatno razvijaju, i nadalje nisu bile u prilici pružiti bolje životne uvjete vlastitom stanovništvu, a kamoli doprinijeti razvoju ostatka Dalmacije. Ipak, u njima su vladali red te primjerena organizacija, pored ostalog, i samog rada. ${ }^{25}$ Postojao je i društveni sloj koji je ne samo bio zainteresiran za napredak već koji ga je, barem na lokalnoj razini, mogao i potaći. Tako je primjerice u Splitu 1767. formirano »Splitsko ekonomsko društvo« koje je za cilj imalo unaprjeđenje poljoprivrede, ribarstva, obrta, trgovine te koje je u tu svrhu objavljivalo odgovarajuću literaturu. ${ }^{26} \mathrm{Da}$ kle, koliko god da su u komunalnoj Dalmaciji uvjeti života ostajali teški, ona je imala predispozicije da uz primjereniju politiku relativno lako iskoristi pogodnosti tijekova koji su vodili napretku.

S druge strane nekadašnje mletačko-osmanske linije razdvajanja bilo je društvo koje je donekle uključivalo elemente komunističke vizije socijalnih odnosa. Unutar njega je, mada u skromnim životnim uvjetima, prevladavala statusna i imovinska jednakost bez vlasništva nad temeljnim izvorom prihoda, tj. nad zemljom. Riječ je bila o jednom gotovo eksperimentalnom društvenoekonomskom modelu koji nije mogao niti valjano zaživjeti. Stoga je na tim prostorima, na kojima je, zbog lišenosti ozbiljnije državne brige, uvelike vladalo bezakonje, narod bio prepušten sebi i prisiljen snalaziti se kako najbolje zna.

\footnotetext{
${ }^{23}$ Usp. Ivan GRGIĆ, Prva agrarna reforma na mletačkoj »novoj stečevini« u Dalmaciji, Split, Izdanja Muzeja grada Splita, 1962; Josip A. SOLDO, Sinjska krajina u 17. i 18 stoljeću (I-II), Sinj, Matica hrvatska, 2011.

${ }^{24}$ Usp. Vjeko OMAŠIĆ, Katastik trogirskog dijela »nove stečevine« iz 1711. godine, Građa $i$ prilozi za povijest Dalmacije, 8 (1974) 8, 79-153.

${ }^{25}$ Usp. Ivo RENDIĆ-MIOČEVIĆ, Zlo velike jetre, Split, Književni krug, 1996, 266-267.

${ }^{26}$ Usp. Grga NOVAK, Povijest Splita (II), Split, Matica hrvatska, 1961, 323-325.
} 
Tek Grimanijevim zakonikom iz 1756. mletačka je uprava pokušala nešto učiniti da bi ti krajevi koliko-toliko valjano profunkcionirali. Međutim, u provedbi tog zakonika nije se daleko stiglo te je uglavnom sve ostajalo po starom. Tako je bilo moguće da gotovo do okončanja mletačke vlasti čak i potencijalno najplodnije zemlje, poput one u Sinjskom polju, ostanu neiskorištene te da rudimentarno stočarstvo bude osnovna privredna djelatnost. ${ }^{27} \mathrm{No}$, ono što je bilo dobro jest to da mletačka vlast nije dopuštala da se unutar takvog sustava ostane bez ičeg, tj. bez zemlje, a time i bez one minimalne gospodarske osnovice. ${ }^{28}$

Dodatnim nevoljama u Dalmaciji pridonosilo je i to što je tijekom 18. stoljeća Mletačka Republika prolazila kroz krize koje su umanjivale njenu nekadašnju efikasnost, otvarale prostor zloupotrebama vlasti te u konačnici pridonijele njenom padu 1797. godine. ${ }^{29} \mathrm{U}$ tim i takvim, prvenstveno ekonomski nepovoljnim uvjetima za narod su posebno značenje imali oni oblici društvenog organiziranja koji su, pored ostalog, olakšavali egzistenciju te osiguravali izvjesnu skrb u nevolji. U priobalju i na otocima tu su ulogu uglavnom imale bratovštine. Mada su primarno bile vjerskog karaktera, okupljanje unutar njih pružalo je i neku vrstu socijalne sigurnosti. ${ }^{30} \mathrm{~S}$ obzirom na to da su im članovi pripadali različitim rodovima, solidarnost koja je proizlazila iz bratovština nije bila uvjetovana rodovskom bliskošću. Nasuprot tome, na teritorijima koji su nekoć bili pod Osmanlijama, najčešće su srodničke veze imale dalekosežno značenje u kontekstu životne organizacije i međusobne ispomoći. Tome je pridonosilo i što su naselja u tim krajevima, nasuprot onima u priobalju i na otocima koja su uglavnom imala »zbijeni« karakter, ponajviše bila skup disperziranih zaselaka nastanjenih srodnicima. ${ }^{31}$ Ove su razlike svojom stabilnošću i trajnošću u bitnome definirale društvene modele unutar Dalmacije, kao i njihov suodnos.

\section{Otočno-primorska i zagoranska Dalmacija}

Za kratkotrajne francuske vlasti otpočele su promjene koje će imati znatan utjecaj na daljnji razvitak odnosa unutar Dalmacije. Posebno će mjesto imati dokidanje dotadašnje i uvođenje nove upravne, tj. upravno-teritorijalne organizacije. Njome će napokon biti nadiđena linija koja je Dalmaciju razdvajala na stare i one za protuosmanskih ratova stečene prostore. Pored toga faktički je demontiran mletački, realno nesvrhoviti krajiški sustav te je zemljišni posjed

\footnotetext{
${ }^{27}$ Usp. Ivan LOVRIĆ, Bilješke o putu po Dalmaciji, Zagreb, Izdavački zavod JAZU, 1948, 51-52.

${ }^{28}$ Usp. Josip A. SOLDO, Grimanijev zakon, Zagreb, Golden marketing - Tehnička knjiga, 2005, 82-83.

${ }^{29}$ Usp. Lovorka ČORALIĆ, Kraljica mora s lagunarnih sprudova. Povijest Mletačke Republike, Samobor, Meridijani, 2004, 150-55; G. NOVAK, Prošlost Dalmacije (II), Split, Marjan tisak, 2004, 24-26.

${ }^{30}$ Usp. Šanjek, nav. dj., 218-226.

${ }^{31}$ Usp. Josip DEFILIPPIS, Dalmatinsko selo u promjenama, Split, Avium, 1997, 95.
} 
predan u vlasništvo njegovim korisnicima. ${ }^{32}$ Navedenim preinakama, koje su nastavile i tijekom naknadne, dugotrajne austrijske vlasti, Dalmacija je napokon u upravnom i ekonomsko-pravnom smislu postajala ujednačenom cjelinom. Riječ je bila o važnim iskoracima koji su trebali biti popraćeni državnom brigom za daljnju konsolidaciju i razvitak Dalmacije. Međutim, do toga nije došlo. Austrija je bila kontinentalna država suženih interesa za mogućnosti koje joj je pružalo posjedovanje gotovo cjelokupne istočnojadranske obale. Tako je unutar njenih okvira Dalmacija, kojoj je nakon 1815. pridružen teritorij bivše Dubrovačke Republike i Boke kotorske, trajno zauzimala mjesto među najnerazvijenijim pokrajinama. ${ }^{33} \mathrm{No}$, za austrijske vlasti barem više nisu bile na snazi nekadašnje mletačke restrikcije kojima je sputavana inicijativa unutar same Dalmacije. Zahvaljujući i tome dalmatinskoj se privredi otvarao prostor za napredak. Prvenstveno unutar onih područja koja su organizaciono i gospodarski već bila konsolidirana, tj. na dijelovima Dalmacije koji nikad nisu bili pod Osmanlijama. Tako u tim krajevima tijekom 19. stoljeća dolazi do znatnijeg razvitka brodarstva, pomorstva, trgovine te do prvih oblika industrijalizacije. Tradicionalno razvijeno vinogradarstvo postat će u drugoj polovici istog stoljeća, u okolnostima koje su mu u kontekstu europskog vinogradarstva išle na ruku, posebno snažnom granom gospodarstva. Toliko da je potaklo ukupan napredak krajeva u kojima je bilo razvijeno. ${ }^{34}$

Na tlu nekadašnje osmanske, odnosno mletačko-krajiške Dalmacije, okolnosti su bile drukčije. Ovdje je 19. stoljeće otpočelo, kako je rečeno, privatizacijom zemljišta koje je u prethodnom vijeku pojedincima i njihovom obiteljima bilo predano na korištenje. Dakle, otpočelo je nekom vrstom pretvorbe. Ona je sama po sebi bila pozitivnim rješenjem s obzirom na to da se konačno stjecao konkretan imetak. No riječ je bila o sredinama s poljoprivredom u povojima i proširenim, ali slabo produktivnim stočarstvom. ${ }^{35}$ Nadalje, zemlja je bila sitno isparcelizirana te se daljnjim umnožavanjem potomstva, po naravi stvari i dalje mrvila. Budući da je sad već bila riječ o vremenu koje je nadilazilo feudalne okvire, valjalo je, jasno od strane države te u određenom (proto)kapitalističkom okviru, omogućiti da se poljoprivreda i stočarstvo osuvremene. Uz ostalo i povezivanjem sitnih posjeda radi uvećanja njihove konkurentnosti. Međutim, narodu je predana zemlja i iznova je prepušten snalaženju. Budući da se nije bilo lako snaći u izrazito nepovoljnim uvjetima, privatizacijom je zemljišta automatski stvorena mogućnost da se ono izgubi te da se ostane bez ičeg. Do toga je najčešće dolazilo tako što se zaduživalo pod pritiskom nepovoljnih ekonomskih

\footnotetext{
${ }^{32}$ Usp. Novak, Prošlost Dalmacije (II)..., 69, 73; Stijepo OBAD, Dalmatinsko selo u prošlosti, Split, Logos, 1990, 19.

${ }^{33}$ Usp. Ivo PILAR, Južnoslavensko pitanje, Varaždin, Hrvatska demokratska stranka - Varaždin, 1990, 390-393.

${ }^{34}$ Usp. Duško KEČKEMET, Kulturna i umjetnička baština u Dalmaciji (II), Split, Marjan tisak, 2004, 229-232, 266-267.

${ }^{35}$ Usp. Soldo, Grimanijev zakon..., 131-134.
} 
prilika, dakako uz pretpostavku da će se dugovi moći vratiti. No u znatnom broju slučajeva nije ih se moglo vratiti te se prepuštalo zemlju. Sve u svemu, otpočinjanjem tadašnje pretvorbe otpočinjala je i svojevrsna, najrazličitijim malverzacijama popraćena prvobitna akumulacija kapitala kojom se unosio dodatni nered u spomenute sredine. ${ }^{36}$ Ona je znatan dio stanovništva potpuno osiromašila, usku je manjinu (dodatno) izdigla, dok je većina jedva uspijevala zadovoljiti osnovne egzistencijalne potrebe. Stoga je dio naroda nalazio rješenje $\mathrm{u}$ iseljavanju. Manjim dijelom $\mathrm{u}$ priobalje i na otoke, a većim u susjednu, do 1878. osmansku, a od te godine do 1918. austro-ugarsku BiH. ${ }^{37} \mathrm{U}$ tim i takvim uvjetima malo što je moglo osigurati napredak, a time i promjenu dotadašnjega društvenog modela.

Pojedine teritorijalne cjeline ipak su se uspjele izdvojiti iz prevladavajućih prilika na tlu bivše osmanske, odnosno mletačko-krajiške Dalmacije te postupno steći društveno-kulturni identitet uvelike sukladan onome koji je vladao na tlu nekadašnjih dalmatinskih komuna. $\mathrm{Na}$ taj su proces poticajno djelovale i nove, za integraciju dalmatinskog življa povoljnije upravne, pravne, teritorijalno-organizacijske, ekonomske prilike. U prvom slučaju riječ je bila o primorskim mjestima uz novigradsko more i u šibenskom zaljevu, o poljičkom i makarskom primorju te o neretvanskom okružju, tj. o Opuzenu i Metkoviću s okolnim naseljima. ${ }^{38} \mathrm{U}$ tim su sredinama negativne refleksije strukturiranja zemljišnih odnosa znatnim dijelom neutralizirane mogućnostima koje je pružao povoljniji geografski smještaj. Moglo se dakle osloniti na ono što pruža more, tj. na pomorstvo, ribarstvo, razvijenije oblike trgovine itd. Pored toga, u tim su krajevima vladali istovrsni agrarno-klimatski uvjeti kao u ostatku otočko-primorskog pojasa što je dodatno utjecalo na to da se postane njegovim integralnim dijelom. Dotle da se pratilo i negativne tijekove koji niti taj pojas nisu mimoilazili.

Krajem 19. i početkom 20. stoljeća vinogradarstvo u Dalmaciji doživljava razoran udar. Prvo zbog nepovoljne politike Beča, a zatim zbog bolesti vinove loze. Time ne da je bio okončan dotadašnji napredak otočno-primorskih sredina, već su se našle u kritičnom stanju. U vremenu napretka glavnina je uloga stavljana na vinogradarstvo. Druge poljoprivredne kulture bile su zapostavljane ili ih se čak iskorjenjivalo da bi se dobio prostor za vinovu lozu. ${ }^{39}$ Nakon što je odjednom izgubila svoje ekonomsko značenje jednostavno nije bilo drugih, razvijenijih izvora prihoda koji bi amortizirali gubitke i omogućili bezbolnije prevladavanje novonastale situacije. Tadašnji slom dalmatinskog vinogradarstva jasno je ukazivao koliko su privredno-razvojne mogućnosti

\footnotetext{
${ }^{36}$ Usp. Obad, nav. dj., 50-51.

${ }^{37}$ Usp. Soldo, Grimanijev zakon..., 144-145.

${ }^{38}$ Usp. Bože MIMICA, Omiška krajina - Poljica - Makarsko primorje. Od antike do 1918. godine, Rijeka, Vitagraf, 2003; Mile VIDOVIĆ, Povijest župa doline Neretve, Metković, Matica hrvatska, 2011.

${ }^{39}$ Usp. Defilippis, nav. dj., 50-60.
} 
otočno-primorskog pojasa, pored svog civilizacijskog kontinuiteta, bile oslabljene stoljetnim osmanskim pritiskom i zapostavljanjem od strane mletačke te austrijske vlasti. Nakon ovog iskustva tek će naknadni modernizacijski procesi, s popratnom industrijalizacijom, omogućiti poboljšanje prilika. U međuvremenu, teški životni uvjeti hrvatskog življa otočno-primorskog pojasa »rješavani« su masovnim seobama u prekooceanske zemlje. Ponajviše u Argentinu i Čile te u Sjedinjene Države.

Drugi tip teritorijalnih cjelina unutar kojih se oblikovao gotovo istovrstan društveni model poput onog u otočno-primorskom području, bile su nekadašnje utvrde-varošice u samoj Zagori. Posebice su napredovale nakon što je omogućeno stjecanje zemljišta i njegov transfer iz posjeda siromašnijih u posjed bolje stojećih. Na taj je način dodatno uzdignut već postojeći "gornji sloj«, a došlo je i do naglog bogaćenja niza pojedinaca. S obzirom na to da su živjeli u tim varošicama ili se u njih naseljavali i one su profitirale njihovim bogaćenjem. Poprimale su sve urbaniji izgled te postajale mjestima u koja, pored državnih službenika, sve više useljavaju i trgovci, intelektualci, obrnici itd. Tako u Zagori nastaju gradići poput Drniša, Vrlike, Sinja, Imotskog, Vrgorca. No tih je gradića bilo malo te nisu znatnije mogli utjecati na opće prilike u zaleđu. Dovoljno je reći da su Imotskome još između dva svjetska rata, u vremenu kad je imao 1.500 stanovnika, gravitirali prostori Zagore i susjedne $\mathrm{BiH}$ površine $2.000 \mathrm{~km}^{2}$, dakle, gotovo veličine Luksemburga. ${ }^{40} \mathrm{U}$ tim je uvjetima glavnina Zagore i nadalje ostajala u izolaciji te je iz prepuštenosti »sebi samoj« i vlastitim problemima, iz nemogućnosti oslonca na povoljnije geo-ekonomske uvjete, zadržavala svoj stoljećima ustaljeni životni ritam.

U svakom slučaju, do konačnog »izlaska« cjelokupne Dalmacije iz zapadnokatoličkog političkog okvira, do kojeg dolazi raspadom Austro-Ugarske 1918., opstala je podvojenost njenog življa između dva društveno-kulturna modela. Na jedan koji je, unatoč svim poteškoćama, uspijevao pratiti tijekove vlastitoga civilizacijskog kruga i drugi koji je uvelike ostajao izvan njega. $\mathrm{Na}$ tu su podjelu primarno utjecale političko-povijesne okolnosti. $S$ tim da je na njihov tijek utjecao i geografski faktor. Tako je Mletačka Republika, kao pomorska država, na tlu današnje Dalmacije, pored otoka, od snažne kontinentalne sile, tj. Osmanskog Carstva mogla obraniti samo dio uskog priobalnog pojasa. Tijekom 19. stoljeća i poslije, geografski je faktor presudno utjecao na to da su nekadašnji osmanski primorski krajevi, za razliku od zagoranskih, većinom uspijevali uhvatiti korak s ostalim otočno-primorskim sredinama. No uspijevale su ga »uhvatiti« i gradske sredine Dalmatinske zagore. $U$ tom smislu rečene se modele, unatoč tome što su se uglavnom preklapali s zemljopisnim zadanostima, tek uvjetno može nazvati, kako ovdje činimo, »otočno-primorskim« i »zagoranskim» (v. zemljovid br. 2).

\footnotetext{
${ }^{40}$ Usp. Ante UJEVIĆ, Imotski. Prilog poznavanju uloge naselja, Geografski glasnik, 18 (1956) 1, 71-88.
} 


\section{Zaključak}

Proces osmanskog osvajanja hrvatskih krajeva kao i njihovo naknadno zauzimanje imao je i na tlu današnje Dalmacije dalekosežne i izrazito negativne posljedice. Najveći dio osvajanih prostora bio je opustošen, podloženi hrvatski živalj izložen je socijalno retrogradnim procesima, obranjeni su krajevi osiromašili za vrijeme stoljetnih sukoba. U tim prilikama, braneći vlastite pozicije na istočnojadranskoj obali, Venecija je dala presudan doprinos obrani zadnjih preostataka južnohrvatskih zemalja. Za razliku od Dubrovnika, ti preostaci nisu imali političke predispozicije koje bi im osigurale mirnu koegzistenciju s osmanskim sultanatom. Obranom otočnog i dijela primorskog pojasa Mletačka Republika nije doprinijela samo obrani života, imovine, civilizacijskog kontinuiteta stanovnika tih krajeva već je omogućila da onoliko koliko su mogli izvrše pozitivan utjecaj na teritorijima koji su naknadno, također zahvaljujući Veneciji, oslobođeni od Osmanlija. No, u toj obrambeno-oslobodilačkoj ulozi zapravo je iscrpljen njen doprinos na dalmatinskim prostorima.

Naime, stare dalmatinske komune proizišle su iz istog rimsko-bizantskog okvira kao i Venecija, razvijale su se na istim društvenim osnovama i težile su, zajedno s primorskim komunama nastalim na hrvatskom državnom tlu vlastitom jačanju i probitcima. Mlečani su ih doduše obranili, no istodobno su ih ekonomski sputavali, onemogućavali im adekvatan oporavak nakon prestanka protuosmanskih sukoba, kao i uspostavu žive veze sa zaleđem. Tom su politikom pokazivali ono što je nazočnošću Osmanlija bilo potisnuto, odnosno da su ipak nekakvi neprijatelji tih komuna koji tek u njihovoj slabosti pronalaze dodatnu garanciju održanju vlastitih pozicija na tlu Dalmacije. Mletačko uvođenje eksperimentalnog i nefunkcionalnog sustava u oslobođenim krajevima te ignoriranje nesređenih prilika u njima, rezultiralo je trajnim i izrazito destruktivnim posljedicama ne samo na područjima gdje je taj sustav uveden već na prostor cijele Dalmacije.

Naknadnu austrijsku, francusku te nanovo austrijsku vlast Dalmacija je dočekala kao zemlja s elementarnim poteškoćama naslijeđenim iz osmanskog i mletačkog razdoblja. Nove su vlasti provodile promjene koje su bile nužne u kontekstu duha vremena, no nisu se trsile trajno apsolvirati uzroke problema. Krajem 19. stoljeća uslijedio je nagovještaj najprimjenjivanijeg oblika nadilaženja privrednog zaostajanja. Tada otpočinju masovni, gospodarskim razlozima potaknuti egzodusi koji se nastavljaju do danas. Druga presudna, uz ekonomiju također povezana slabost Dalmacije, bila je u njenoj podvojenosti između dva društvena modela. Na onaj koji je u konačnici, osim na otocima, prevladao u kompletnom primorju, neretvanskom kraju i gradskim središtima zaleđa te na onaj koji je dominirao u Zagori. Sve u svemu, problematično stanje, trasirano na prekretnici 15. u 16. stoljeće »provuklo« se do samog pada austrijske vlasti i otpočinjanja ubrzanih modernizacijskih procesa u koje Dalmacija ulazi s ozbiljnim invaliditetom. 
Temeljni problemi Dalmacije bili su političke naravi, bili su uočljivi i političkom su se voljom mogli rješavati. Radi toga da napokon stekne ekonomsku funkcionalnost i društvenu ujednačenost. Pretpostavke koje su mogle pružiti gospodarski, a time i sveukupan polet Dalmacije osigurane su nakon Morejskoga i Malog rata. Kombinacijom potencijala komuna i valjanom organizacijom zemljišta koje je tada stečeno, dalmatinska je zbilja mogla biti daleko povoljnija. Osmanska osvajanja i vlast su stvorili problem, no spomenuta dva rata zbila su se na prekretnici 17. u 18. stoljeće. Nakon njih vlast nad Dalmacijom do 1797. ima Venecija, od 1797. do 1805. Beč, od 1806. i 1813. Pariz te nanovo Beč do 1918. Dakle, sve odreda izuzetno jaki, predvodnički centri zapadnog kulturnog kruga. Preciznije, onog njegova segmenta koji je, poput Dalmacije, u bitnome bio određen katolicizmom. I tijekom dvjestogodišnje vlasti tih i takvih centara u zaleđu se Dalmacije, što je posebice porazno u bitnome održava društveni model koji je proizišao iz segregacijskih uvjeta pod kojima je kršćanski svijet živio u osmansko-islamskom kalifatu.

Za hrvatski narod stvarnost koja je nastajala s Osmanlijama bila je ravna biblijskim kataklizmama. U tim uvjetima i Venecija i Beč bili su poput zadnjih spasonosnih svjetionika. Dok je njihova vlast trajala hrvatski im je narod, sukladno pogubnom iskustvu s osmansko-islamskim Istokom, u osnovi bio vjeran. Tako su, uoči pada Venecije te 1797. godine jedino dalmatinske postrojbe iskazivale spremnost da je brane od francuske okupacije. ${ }^{41}$ Pod zastavom Sv. Marka u Dalmaciji se dizalo ustanke i ratovalo protiv tih istih, kako se držalo, »bezbožnih« Francuza i to godinama nakon što je Mletačka Republika nestala sapolitičke karte. ${ }^{42}$ Austrijska je vlast u Dalmaciji uspostavljena u vremenu u kojem je odavno nadiđena osmanska prijetnja i u kom je protuosmanski epski ciklus ulazio u svoju završnicu. Stoga veza Dalmatinca i Beča, pod kojim se uglavnom živjelo u mirnoj, ustaljenoj svakodnevnici, nije bila prožeta zajedničkim povijesno-emotivnim nabojem. Ipak, nakon novog iscrpljujućeg iskustva »Istokom«, ovog puta u obliku Jugoslavije, u Dalmaciji se o vladavini Austrije, o njenom dugovječnom caru Franji Josipu (1848-1916) u pravilu govorilo s nostalgijom. Sve je to skupa važno, no ne umanjuje činjenicu da je stanje u Dalmaciji i poslije Venecije i poslije Beča bilo porazno s ekonomskog i društveno-kulturnog aspekta. Još je gore bilo na razini nacionalno političkih tendencija koje postaju aktualne tijekom 19. stoljeća, dakle za vladavine Austrije, a koje ovdje nisu niti razmatrane. No, kako bilo, Dalmacija je, uza sve pogibelji koje su joj prijetile, uspjela ostati zemljom u kontinuitetu očuvanih, najboljih vrijednosti Carstva koje stoji na početku priče o Zapadu. Jednako tako i zemljom kojoj je spoznaja da je upravo na »njenom « tlu bilo srce »nekoć slavnoga Hrvatskoga Kraljevstva«, sugerirala da jednom mora doći do uzleta.

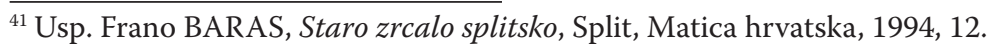

${ }^{42}$ Novak, Prošlost Dalmacije (II)..., 71.
} 


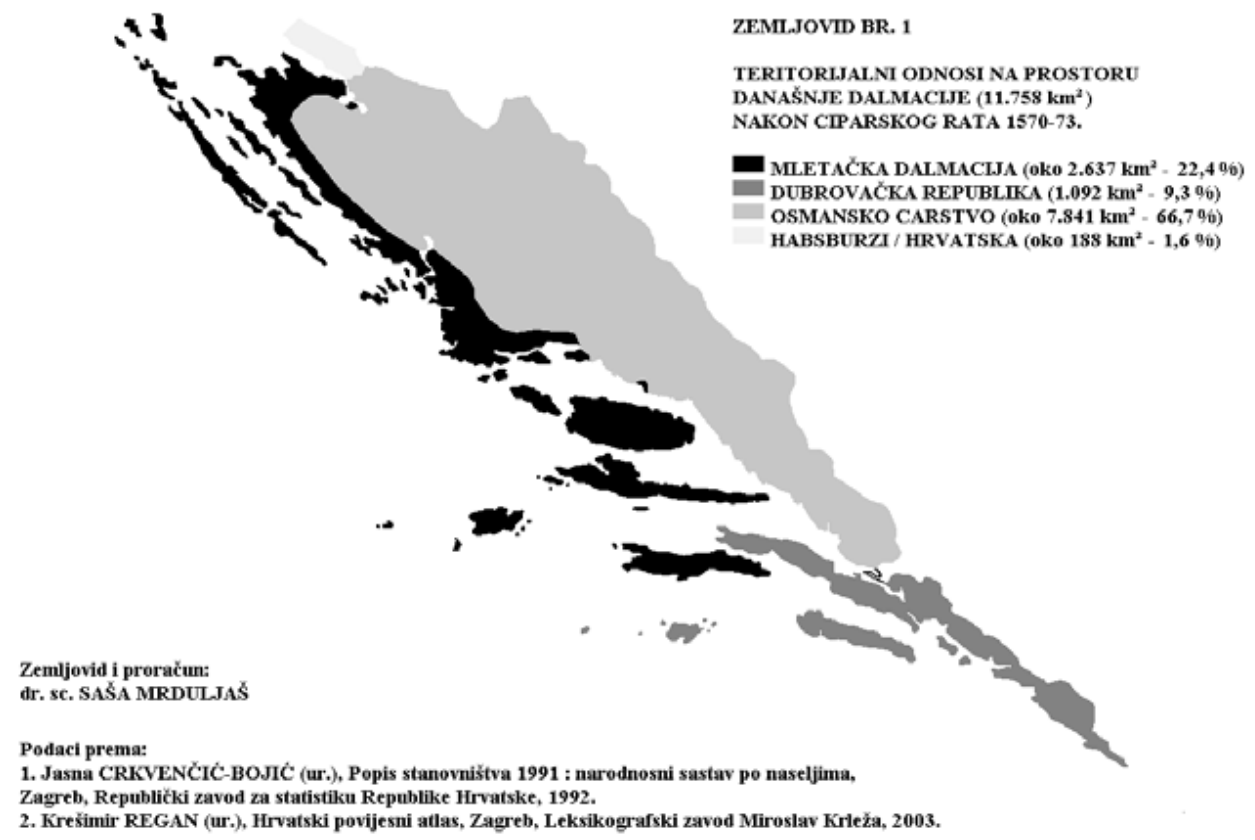

Zagreb, Republički zavod za statistiku Republike Hrvatske, 1992

2. Krešimir REGAN (ur.), Hrvatski povijesni atlas, Zagreb, Leksikografski zavod Miroslav Krieža, 2003.

Zemljovid izradio:

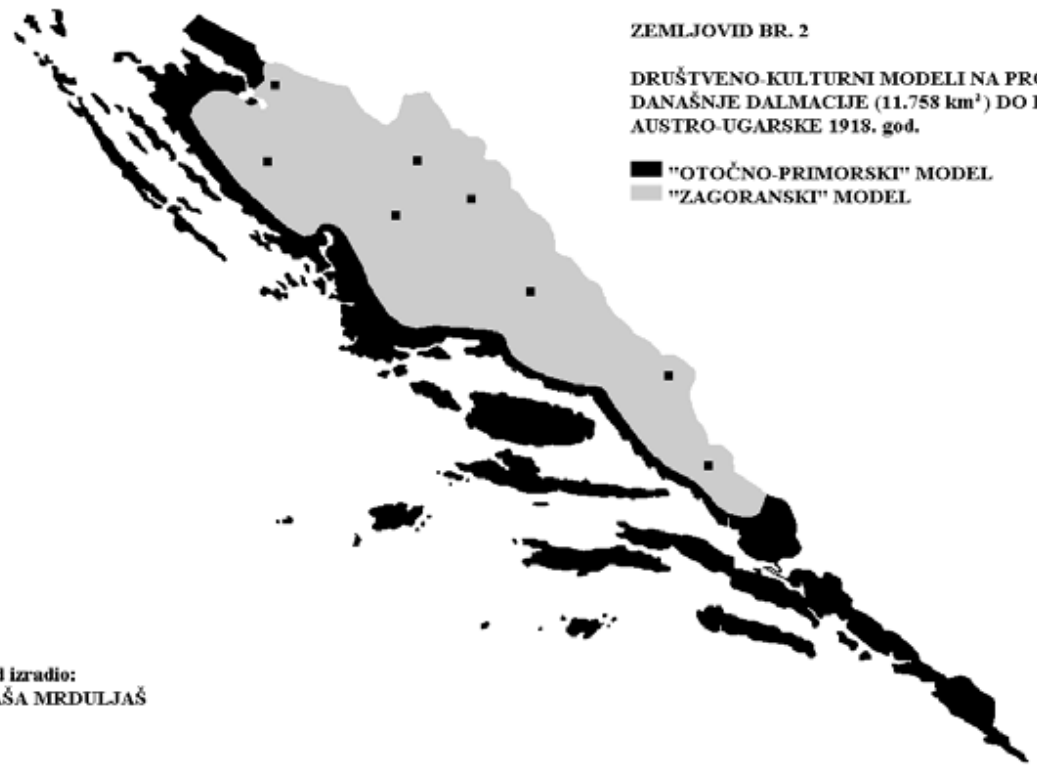




\section{Saša Mrduljaš* \\ The Causes of Socio-Cultural Diversities of Insular-Coastal and Tramontane Region of the Dalmatia \\ Summary}

Up to close of the Middle Ages Croatian areas, in consistence with different political, geographical and foreign influences manifested specific particularities and developmental unhomogeneousnesses. In spite of all that, they represented socio-cultural compatible unity, which was steadily deep-rooted in its own civilization and mainly managed to go along with developmental streams within it. With Ottoman conquests which begin in the midst of 15 century, important changes had happened in this regard. Civilization continuity was preserved only on defended territories, that is in north-west Croatia, insularcoastal belt under Venetian authotity and in Dubrovnik Republic. On the conquered territories Ottomans completely erased western social structure. For Croats in those areas the only connection to own civilization was Catholic Church, essentially restricted on the Franciscan order. In this paper we analyze the changes which in socio-cultural context took place within the framework of present-day Dalmatia during the Ottoman control of significantly part of its territory. We also analyze the reasons why these changes, which had happened during the Ottomans, succeeded to preserve its importance even after the liberation of these territories during the Venetian, French and Austrian authorities.

Key words: Dalmatia, Croats, Venetian Republic, Ottoman Empire, social relations.

(na engl. prev. Ivo Sokol)

\footnotetext{
* Saša Mrduljaš, PhD, senior research associate of Institute of Social Sciences Ivo Pilar - Regional Centre Split; Address: Poljana kraljice Jelene 1/1, HR-21000 Split, Croatia; E-mail: Sasa. Mrduljas@pilar.hr.
} 